Dermatology 1992;184:1

\title{
From Dermatologica to Dermatology
}

\begin{tabular}{|l|l|l|}
\hline J.-H. & Saurat \\
\hline
\end{tabular}

\section{Geneva}

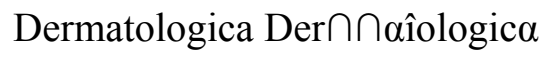

Dermatologica

This publication first appeared in 1893 as a German-language journal entitled Dermatologische Zeitschrift.

Dermatologische Zeitschrift.

Dermatologische Zeitschrift

Dermatologische Zeitschrift

D er ma tologica

Dermatologica

As the first journal to be launched by the Karger publishing house, its early success paralleled the rapid growth of dermatology as a medical discipline.

By 1939 the title of the journal had changed to Dermatologica -a logical step for a journal which was then publishing papers in German, French, Italian and English.

However the trend towards English as the universal language of science and medicine has meant that submissions to the journal over the past few years have been exclusively in English.

The change of title to Dermatology now reflects this evolution. 